\title{
ESTRATEGIAS DE ARCHIVO Y ORDEN SOCIAL EN LA GUERRA CIVIL ESPAÑOLA Y LA DICTADURA FRANQUISTA
}

\section{Archival strategies and social order during the Spanish Civil War and the Francoist dictatorship}

\section{Guillermo Pastor Núñez}

Cuerpo Facultativo de Archiveros del Estado guillermopastornun@gmail.com Orcid: 0000-0002-8710-0279

\section{Henar Alonso Rodríguez}

Cuerpo Facultativo de Archiveros del Estado henarart@gmail.com Orcid: 0000-0003-3274-1789

\section{María del Carmen Rial Quintela}

Cuerpo Facultativo de Archiveros del Estado mriaqui@gmail.com Orcid:0000-0002-7363-1423

Recibido: 16-06-2020 - Aceptado: 12-10-2020

Cómo citar este artículo/Citation:

Guillermo Pastor Núñez, Henar Alonso Rodríguez, María del Carmen Rial Quintela, "Estrategias de archivo y orden social en la Guerra Civil española y la dictadura franquista", Hispania Nova, 19 (2021): 545-584

DOI: $\underline{\text { https://doi.org/10.20318/hn.2021.5891 }}$
Copyright: (C) HISPANIA NOVA es una revista debidamente registrada, con ISSN 1138-7319 y Depósito Legal M 9472-1998. Los textos publicados están -si no se indica lo contrario- bajo una licencia Reconocimiento-Sin obras derivadas 3.0 España de Creative Commons. Puede copiarlos, distribuirlos y comunicarlos públicamente siempre que cite su autor y la revista y la institución que los publica y no haga con ellos obras derivadas. La licencia completa se puede consultar en: http://creativecommons.org/licenses/by-nd/3.0/es/deed.es
Resumen: Este estudio presenta una reflexión sobre la capacidad de los archivos para revelar la naturaleza del orden social que los genera, especialmente en situaciones políticas actuadas por dinámicas de conflicto y resistencia. Como paradigmas de esta capacidad del archivo, se han seleccionado tres casuísticas documentales de la Guerra Civil y la dictadura franquista: en primer lugar, tres archivos del orden social no sublevado; en segundo lugar, el archivo del Servicio de Información y Policía Militar, presentando sus series menos exploradas; finalmente, los sumarísimos, por su condición de documentación de obligada referencia en investigaciones sobre la represión franquista.

Palabras clave: Archivos, Guerra Civil española, Exilio, Orden social, Represión, Franquismo.

Abstract: This study presents a reflection on the ability of archives to reveal the nature of the social order that generates them, especially in political situations acted on by dynamics of conflict and resistance. As paradigms of this ability of the archives, three samples of the Spanish Civil War and the Francoist dictatorship have been selected: 
first, three archives of the non-rebeled social order; secondly, the archive of the Servicio de Información y Policía Militar, introducing the less explored series; finally, the sumarísimos, due to its condition of documentation of required reference in researches on Francoist repression.
Keywords: Archives, Spanish Civil War, Exile, Social order, Repression, Francoism.

\section{INTRODUCCIÓN}

El artículo que se presenta tiene como objetivo contribuir a la comprensión del archivo, reflexionando críticamente sobre su doble carácter de sujeto-objeto dentro de la situación política y social de cada momento. Para ello, se presentan como caso de estudio diferentes fondos documentales cuya selección responde a su capacidad de reflejar el orden social que los generó dentro de una realidad compleja como fue la conformada por las relaciones de complicidad, conflicto y resistencia de la Europa del periodo 1936-1947, y en especial, por los procesos de hegemonía o marginación política y social que marcaron la Guerra Civil española y la dictadura franquista.

El primer apartado analiza las estrategias ejercidas sobre los archivos de los grupos sociales que perdieron la Guerra Civil: comienza explicando la destrucción de archivos como elemento integrante de la acción revolucionaria anarcosindicalista, acotando ese componente de la memoria colectiva que atribuye a grupos revolucionarios cualquier vacío documental anterior a 1936. A continuación, se expone el proyecto de Archivo de la Guerra republicano como construcción archivística ideológicopropagandística, un archivo fundacional que las consecuencias de la derrota bélica difuminaron en un voluminoso conjunto de patrimonio bibliográfico. Este primer apartado finaliza reflexionando sobre archivos exiliados, no por su relevancia individual como fuente documental, sino como paradigmas de la mutación sufrida a causa de su condición de conjuntos documentales trasterrados, en combinación con el paso del tiempo y las voluntades personales.

Las estrategias documentales y archivísticas que concurrieron en apoyo de la victoria del bando nacionalista en la Guerra Civil son más conocidas por haber estado 
acogidas a la protección institucional durante la dictadura y tras ella, una vez corregida su significación durante la Transición. Están profusamente estudiadas iniciativas como el "Archivo de la Guerra de Liberación", el archivo de antecedentes políticos creado por la Delegación de Estado para la Recuperación de Documentos (DERD) o la conocida "Causa General"1.

Por ello, el segundo apartado se refiere a una documentación apenas explorada del Servicio de Información y Policía Militar (SIPM), como una de las principales estrategias del bando nacionalista para la ocupación y control social de la población. El apartado comienza explicando el proceso de monopolización de la información militar, para a continuación detallar la gestión documental que ejerció el SIPM, todo ello basado en el examen de la normativa interna y de la propia documentación. Finaliza el segundo apartado exponiendo el uso postrero del fichero del SIPM como estrategia para el control social sobre los militares.

El tercer y último apartado se concentra en el análisis de la naturaleza de los sumarísimos como producto documental de la jurisdicción de Guerra imperante durante la Guerra Civil y la dictadura franquista ${ }^{2}$, con el objetivo de afianzar la verdadera identificación de estos expedientes. Empieza el tercer apartado exponiendo las anomalías regulatorias y de aplicación utilizadas por los juzgados militares y los Consejos de Guerra para cimentar el orden social de la dictadura. A continuación, se contrastan los sumarísimos con las causas militares del período anterior, marcando la diferente función a la que sirvieron unos y otras bajo una apariencia muy similar. Por último, se explican algunas estrategias archivísticas que reforzaron la apariencia judicial de los sumarísimos.

\footnotetext{
${ }^{1}$ Entre la amplia doctrina archivística sobre estos fondos documentales, destacamos el enfoque de Antonio González Quintana, "Fuentes para el estudio de la represión franquista en el Archivo Histórico Nacional, sección Guerra Civil”, Espacio, Tiempo y Forma, Serie V, Historia Contemporánea, 7 (1994), pp. 479-508. Más reciente, se puede consultar a Jesús Espinosa Romero, "El Archivo de la Guerra Civil en Salamanca: de la campaña a la transición”, en Paseo documental por el Madrid de antaño (2015), $131-155$

${ }^{2}$ Sobre los sumarísimos existen numerosos estudios historiográficos que sería imposible referenciar aquí, inevitablemente limitados cronológica y/o territorialmente por las dimensiones y complejidad de este conjunto documental. También existen algunas contribuciones desde la Archivística, de valor descriptivo o como instrumento de referencia, que serán mencionadas.
} 
La lectura de este artículo debe tener presentes tres conceptos fundamentales: en primer lugar, se considera "estrategia archivística" todo aquel uso de las prácticas o técnicas de carácter documental o archivístico aplicadas sobre la documentación para alcanzar una finalidad de poder o supervivencia que se suma a su función ordinaria, bien por la institución productora, bien por los sujetos que en algún momento ejercen su custodia. El orden social puede ser definido como la construcción de las relaciones de dominación y alianza dadas entre diferentes grupos sociales, mientras que con archivo nos referiremos siempre a la realidad archivo-orgánico, es decir, al conjunto orgánico de documentos acumulado en el ejercicio de una determinada función, y no al archivorepositorio, como institución de custodia.

Este trabajo no pretende añadirse a las contribuciones de las personas que, con un conocimiento profundo del contexto histórico, acuden a las salas de investigación de los archivos-repositorio, revisan los inventarios, interpretan su contenido y usan los documentos consultados para localizar más información sobre el tema de su interés. Pero el hecho es que la corpulencia de la mayoría de los $\operatorname{archivos}^{3}$ hace que únicamente los archiveros tengan a su alcance la posibilidad de realizar determinados análisis cualitativos que requieren el examen de grandes cantidades de documentación, así como que sean los primeros en realizar el examen de la disposición física original en legajos o de los inventarios realizados por las oficinas productoras.

Todo ello es necesario para su trabajo de facilitar la puesta a disposición de la documentación, y para ello cuentan con una formación y experiencia especializadas, pero además es el único modo en el que pueden ser realizadas investigaciones sobre la mecánica interna y externa de cada uno de los archivos como conjunto orgánico completo ${ }^{4}$. Conociendo desde dentro las energías que el archivo-repositorio ejerce sobre los documentos lo suficiente como para neutralizar su influencia, quienes suscribimos este trabajo hemos dirigido nuestra mirada hacia "el documentar" y hacia las estrategias

\footnotetext{
${ }^{3}$ A partir de este momento, el término se utiliza en el sentido de archivo-orgánico, salvo que del tenor del texto se deduzca claramente lo contrario.

${ }^{4}$ El presente trabajo se aleja deliberadamente de las tradicionales aportaciones sobre fondos documentales que reproducen el esquema marcado por los estándares archivísticos internacionales en artículos de revista o capítulos de monografías o que se concentran en ofrecer agrupamientos temáticos de fuentes primarias disponibles para la investigación y en desgranar los cuadros de clasificación de los archivosrepositorio.
} 
que hicieron que determinados archivos condicionasen el orden social de un modo determinado, y no de otro.

\section{NEGACIÓN, CONSTRUCCIÓN Y EXILIO DE ARCHIVOS}

\section{Negación de archivo}

La primera consideración sobre los documentos y los archivos en un conflicto social, político y bélico es su eliminación voluntaria, por oposición a su afirmación, es decir, su existencia. Durante la Guerra Civil española la revolución libertaria puso en práctica la eliminación de determinados archivos como trasunto de la destrucción del orden social que sustentaban, constituyendo este ejercicio un elemento de su programa político.

En Barcelona, sofocada la sublevación militar, un Comité Revolucionario ocupó el Palacio de Justicia con el objetivo de establecer un nuevo modelo de justicia revolucionaria. La reacción por parte de la Generalitat de Catalunya consistió en orientar esta iniciativa espontánea hacia la legalidad, mediante la creación y limitación de funciones de las Oficinas Jurídicas de Cataluña ${ }^{5}$. El texto dispositivo del decreto expone su función como un organismo de asesoramiento legal para las asociaciones obreras, aunque revela una peculiar capacidad para la revisión de causas.

El nombramiento para su jefatura de Eduardo Barriobero, abogado defensor de anarcosindicalistas y miembro del grupo de parlamentarios radicales conocido como los jabalis ${ }^{6}$, impulsó el papel de esta Oficina que rebasó, con sus iniciativas, sobradamente las competencias señaladas. Pero lo más interesante fue el estudio de la documentación de los archivos del Palacio de Justicia de Barcelona y su selectiva eliminación. Relata Barriobero que, al ocupar su cargo de jefe de la Oficina Jurídica de Barcelona, en 17 de

\footnotetext{
5 José Luis Villar Ferrero, “Justicia y Revolución en 1936. Las Oficinas Jurídicas de Cataluña” (Tesis doctoral, Universitat de Barcelona, 2012).

${ }^{6}$ José Luis Carretero Miramar, Eduardo Barriobero. Las luchas de un jabalí. (Madrid: Queimada, 2017).
} 
agosto de 1936, preguntó qué había hecho el Comité Revolucionario de Justicia hasta el momento, recibiendo como respuesta ${ }^{7}$ :

Quemar papeles [...] Es lo que más prisa corre a las sindicales vejadas por la Justicia pretérita. Cada noche se llevan los Comités de Defensa un par de toneladas de procesos para hacer el auto de fe en las estribaciones de Montjuich.

El Comité Revolucionario de Justicia se afanaba, desde la ocupación del edificio, en la destrucción de los procesos judiciales como un acto de justicia, asimilándolo en el embellecido relato de Barriobero, a un auto de fe. No obstante, y para despejar las dudas sobre un ejercicio indiscriminado de destrucción compulsiva, el propio Eduardo Barriobero introduce criterios muy precisos sobre estas eliminaciones documentales. Siguiendo el hilo su propio relato ${ }^{8}$ :

Eso está bien. Pero supongo que separaréis las piezas de fianza. [...] Como los resguardos de Hacienda de la Generalidad, o del Banco están en su poder, estáis quemando a beneficio suyo los documentos de referencia. Estáis brindándoles una buena parte en el botín de la Revolución.

La eliminación documental es, sigue siendo, un instrumento fundamental en los archivos y su aplicación no es un ejercicio sencillo. Debe guardar suficientes garantías para eliminar aquello que es prescindible y discernir lo que sí guarda valor y se debe conservar. Barriobero, según sus propias palabras, llevó a cabo una operación de valoración técnica documental, dando cuenta del error que suponía eliminar esa determinada parte de la serie documental, tal y como los anarcosindicalistas estaban haciendo, cuya desaparición podría servir al interés del orden social que pretendían derribar.

Coincidiendo en el tiempo, pero en Valencia, en septiembre de 1936 una de las más conocidas unidades militares anarquistas toma su iniciativa de destrucción de archivos. Alejados del frente, sus componentes entran en Valencia y destruyen los

\footnotetext{
${ }^{7}$ Eduardo Barriobero y Herrán, El Tribunal Revolucionario de Barcelona, 1936-1937. (Sevilla: Espuela de Plata, 2007), 59.

${ }^{8}$ Ibídem.
} 
archivos de la Audiencia Territorial y el Registro de la Propiedad ${ }^{9}$. No es un acto de naturaleza criminal, ni un impulso descontrolado de algunos anarquistas aprovechando la debilidad del orden público. En defensa de las inmediatas acusaciones de índole criminal que recibieron sobre su actuación, redactan un manifiesto donde defienden sus actos, pero, sobre todo, exponen programáticamente determinadas acciones para la retaguardia ${ }^{10}$ :

\section{Desarme total y disolución de la Guardia Civil.}

2. Inmediato envío al frente de todos los cuerpos armados.

3. Destrucción de todos los archivos y ficheros de las instituciones capitalistas y estatales.

Los firmantes del manifiesto proponen la destrucción de los archivos como un elemento de su programa revolucionario. No es, por tanto, el resultado de acciones vandálicas, descontroladas, inopinadas o espontáneas, vinculadas a comportamientos criminales como era interpretado con frecuencia por la opinión pública, recordando el origen presidiario de muchos de sus componentes. Resultó, por el contrario, la ejecución de una línea de acción política.

Y, mientras tanto, en Madrid, en aquellos días que la capital del Estado abandonaba el centro de España, el 4 de noviembre, Largo Caballero anuncia un cambio de gobierno con la entrada en él de cuatro ministros de la CNT. Esta iniciativa perseguía, entre otros objetivos, controlar el impulso revolucionario, reconduciendo su actividad para la defensa de la República. Si el control del aparato judicial y la militarización de las columnas de milicianos anarquistas permitieron detener las destrucciones de archivos en Cataluña y el País Valenciano, la entrada en el Ministerio de Justicia del anarcosindicalista Juan García Oliver contribuyó a retomar y dar continuidad a esta estrategia revolucionaria documental desde, nada menos, el principal despacho del Ministerio de Justicia.

\footnotetext{
${ }^{9}$ Miquel Amorós, José Pellicer. El anarquista íntegro. Vida y obra del fundador de la heroica Columna de Hierro (Barcelona: Virus Editorial, 2009), 132 y ss.

${ }^{10}$ Fragua Social, 7 de octubre de 1936, pág. 2.
} 
García Oliver, informado de su nombramiento en Barcelona, acude cuando le es posible a Madrid, de donde el gobierno va a trasladarse a Valencia de inmediato. En sus memorias revela valiosos detalles sobre estos días. Al visitar el Ministerio de Justicia le comunican que el último bombardeo había destruido parcialmente el registro de antecedentes penales, a lo que el recién nombrado ministro responde ordenando la destrucción total del mismo. Y añade que, para evitar los efectos de una reconstrucción del fichero, firmará un decreto para la cancelación de todos los antecedentes penales ${ }^{11}$, ampliando las medidas tomadas en un decreto del mismo asunto anterior, firmado por su antecesor, Mariano Funes, justo antes de cesar como ministro.

Una maniobra que, en su delicado papel de líder revolucionario y, al mismo tiempo, miembro del Consejo de Ministros, representa un estentóreo argumento a favor de la participación del anarcosindicalismo en el gobierno, demostrando la posibilidad de compaginar el desempeño como ministro y la actividad revolucionaria. Llegado a este punto, la más alta instancia gubernativa en materia de Justicia revela en sus memorias esta insólita actividad ${ }^{12}$ :

El día siguiente, muy de mañana, nos fuimos al Ministerio. Habia que quemar las (sic) miles de fichas del Archivo nacional de antecedentes penales, utilizando todas las estufas del edificio.

Puede confrontarse este fragmento desde, lo que podríamos denominar, tomándonos cierta licencia, el programa político sobre documentos y archivos opuesto, la Causa General, en la "Declaración prestada por don Luis Palud Clausó, testigo presencial de la destrucción de los archivos del Registro Central de Penados y Rebeldes, realizada por el ex presidiario Juan García Oliver, ministro de Justicia del Frente Popular"13.

Esta poderosa estampa de un ministro destruyendo uno de los principales archivos de su competencia fue la culminación del programa de negación del archivo que hundía sus raíces en una actividad insurreccional anarcosindicalista reemprendida

\footnotetext{
${ }^{11}$ Juan García Oliver, El eco de los pasos. (París: Ruedo Ibérico, 1978), pág. 321. El decreto fue firmado por García Oliver en 19 de diciembre de 1936, profundizando y generalizando la cancelación decretada por su antecesor, Mariano Funes, en 2 de noviembre. Gaceta de la República,

12 Ibídem, pág. 322.

${ }^{13}$ MINISTERIO DE JUSTICIA, 1943. Causa General. (León: Akrón, 2008), pág. 439.
} 
con especial intensidad desde la proclamación de la II República. En las diferentes oleadas de insurrecciones libertarias, especialmente intensas en el ámbito rural, se ejercitó la revolución a pequeña escala y siempre con el mismo infructuoso resultado. No obstante, esta actividad ayudó a familiarizar a la comunidad anarcosindicalista con un programa revolucionario que fue sintetizado por Josep Peirats en cinco fases, según su propio estudio de los acontecimientos, en cuya fase tercera ${ }^{14}$ :

Los revolucionarios proclaman el comunismo libertario desde el Ayuntamiento, convertido en comuna libre. Se iza la bandera rojinegra. Los archivos de la propiedad son quemados en la plaza pública, ante los grupos de curiosos. Se hace público un bando o pregón declarando suprimidas la moneda, la propiedad privada y la explotación del hombre por el hombre.

En 1932 y 1933, en diversos momentos y en determinados contextos, se reprodujo este modelo insurreccional que proclamaba el "comunismo libertario" y que tuvo siempre el mismo fatal resultado de detenidos y muertos por la intervención de las fuerzas de orden público. En diciembre de 1933, y como respuesta a la victoria de las derechas en las elecciones generales, se produjo una oleada de insurrecciones más intensa, donde quedan acreditadas numerosas cremaciones de documentos. Los protagonistas confirieron a sus acciones, no sólo su voluntad decidida, sino también su perspectiva cultural y política. Según recoge "Tierra y Libertad" en San Asensio (La Rioja) ${ }^{15}$ :

Los revolucionarios, ya dueños del pueblo, se apoderaron del Ayuntamiento, requisaron las armas y quemaron el archivo, no sin antes examinar si el mismo contenía algún elemento que fuese útil al desarrollo de la cultura popular. Y como en el archivo se hallasen algunos tomos de la Enciclopedia España, fueron conservados con esmero.

Con cada eliminación de documentos se perseguía un doble objetivo: la destrucción del orden social que sustentaban respecto a los registros de propiedad, y la reparación de los años de presidio, torturas y ejecuciones que muchos miembros de la gran familia anarquista habían afrontado en el pasado cercano respecto a los

\footnotetext{
${ }^{14}$ Josep Peirats, La CNT en la Revolución Española. Tomo I. (CNT-AIT: Madrid, 1978), 68.

${ }^{15}$ FAI-CNT, "La insurrección anarquista del 8 de diciembre, Su origen, su significado y su desarrollo", Tierra y Libertad, Suplemento de 1934.
} 
antecedentes penales. Prendida la gran hoguera formada por los documentos en estos años de insurrecciones, el fuego se avivará al iniciarse la Guerra Civil y, finalmente, decaerá junto a la influencia del anarcosindicalismo. La huella que han dejado en nuestros actuales archivos es un poderoso y elocuente vacío, un signo de archivo mediante su negación. Su contrario, la afirmación del archivo, corresponde a la ya mencionada exhaustiva producción documental que acompaña a la apertura de la Causa General, donde pueden encontrarse abundantes testimonios de estas destrucciones.

\section{Construcción de un archivo ideológico}

La República Española, tras los primeros meses de fragilidad del Estado, activó todos los instrumentos posibles para reorganizarse o, cuanto menos, ser capaz de resistir durante el mayor tiempo posible frente a un enemigo que poseía el recurso decisivo para la victoria en un conflicto bélico, las armas. La movilización implicó también a la política cultural, al Tesoro Artístico, las Bibliotecas y también a los Archivos. El Patrimonio Cultural fue movilizado y tuvo un importante papel ideológico y también propagandístico, pero durante los primeros meses la iniciativa social no se encontraba en las instituciones del Estado, sino al margen de ellas. La actividad del Ministerio de Instrucción Pública se limitó en aquellos primeros momentos de desconcierto a la depuración de funcionarios, mientras que la verdadera movilización del ámbito de la Cultura correspondió a aquellas asociaciones, comités y grupos políticos protagonistas de los primeros días de resistencia frente la sublevación militar y de revolución ${ }^{16}$.

Las actividades de una de esas asociaciones con mayor proyección internacional, la Alianza de Intelectuales Antifascistas, eran tan variadas como todas las artes, disciplinas y especialidades académicas de sus miembros o simpatizantes, y basta repasar el listado de nombres de los firmantes de su manifiesto en defensa de la Cultura para corroborarlo ${ }^{17}$. Ya en septiembre, un reportaje del semanario Mundo Gráfico relaciona todas las actividades del llamado "frente de intelectuales" comprometidos con la causa de la república, siendo una de ellas la creación de un "archivo de la guerra": "Se

\footnotetext{
16 José Álvarez Lopera, La política de bienes culturales del gobierno republicano durante la guerra civil española, vol. I (Madrid: Ministerio de Cultura, 1982), 26 y ss.

${ }^{17}$ La Voz de Madrid, 30 de julio de 1936.
} 
compondrá de materiales inéditos y publicados, fotográficos y literarios, que, reunidos dentro de unos quince días, formarán un libro documental magnifico "18.

Aunque la formulación es rudimentaria y no hay prueba de su existencia, sirvió para que la Junta Delegada de Defensa de Madrid retomara esta iniciativa utilizando como sede improvisada la Hemeroteca Municipal de Madrid y, finalmente, en agosto de 1937, el Ministerio de Instrucción Pública creará como iniciativa gubernamental "E1 Archivo de la Guerra", con medios públicos. A partir de este momento empezó a crecer y a recibir unos testimonios documentales que fueron ampliando su tipología, abarcando fotografías, periódicos murales y material de propaganda, aunque durante el tiempo que estuvo Jesús Hernández al frente del ministerio no pudo ampliar su ámbito territorial más allá de la provincia de Madrid ${ }^{19}$.

Con el cambio de cartera en el Ministerio de Instrucción Pública en abril de 1938, en favor del cenetista Segundo Blanco, llegarán las medidas más enérgicas para relanzar el Archivo de la Guerra como un proyecto que abarque todo el territorio el territorio todavía bajo el control de la República. Se adoptaron fórmulas para que el acopio de documentos aumentase, como fueron la participación de la red de maestros de escuela o una dotación generosa de medios económicos, al mismo nivel que el resto de los archivos nacionales.

Durante este período se traslada a Barcelona y es nombrado Diego Abad de Santillán como su director. Además de la encomienda a los maestros de enseñanza, el Archivo de la Guerra continuará con sus requerimientos para recabar nuevos testimonios. Estas cartas enviadas a todas aquellas asociaciones, organismos oficiales, partidos políticos, sindicatos, grupos de afinidad, ateneos, unidades militares, etc. que habían publicado testimonios apropiados para este archivo quedaron en las secretarías de las citadas entidades. La incautación que de sus archivos hizo el bando nacionalista ha provocado que gran parte de esta correspondencia se encuentre en el Centro Documental de la Memoria Histórica ${ }^{20}$. Mientras duró la última parte de la guerra, la

\footnotetext{
${ }^{18}$ Mundo Gráfico, 2 de septiembre de 1936.

${ }^{19}$ Guillermo Pastor Núñez, "Un archivo vivo de la Guerra Civil española. El auténtico archivo de la guerra” en Kamchatka. Revista de análisis cultural, 14 (2019), 93-110.

${ }^{20}$ Ibidem.
} 
sede este archivo en Barcelona fue acumulando folletos, fotografías, carteles y todo tipo de materiales hasta la ocupación de la ciudad por las tropas franquistas. Debido a su gran volumen fue incautado, pero no trasladado íntegramente a Salamanca o Madrid. Una copia de una memoria referente a 1937 hecha por quien se incautó del archivo nos indica que fue llevada alguna muestra para su estudio ${ }^{21}$ :

POSIBLE UTILIZACIÓN DEL ARCHIVO DE LA GUERRA [sic]. Quizá pudiera parecer interesante el remitir alguno de los apartados ya mencionados (libros, folletos, revistas, carteles murales, tarjetas de campaña...) para el Servicio Histórico del Ministerio del Ejército o al Organismo que se estime conveniente, como antecedentes para un posible estudio más detenido en su día de la Guerra Psicológica.

Este texto marca el camino de resignificación que tendrá este archivo vivo, abruptamente clausurado por la ocupación franquista de Barcelona. A partir de su incautación el archivo pasa a ser examinado por su contenido ideológico y, con el tiempo, arrumbado y desfigurado por la falta de control sobre sus piezas. La fortuna hizo que el mayor volumen, quedase en los depósitos de la Universidad de Barcelona, de donde fue rescatado y resignificado como patrimonio bibliográfico en el Centre de Recursos per a l'Aprenentatge i la Investigació "Pavelló de la República", como su principal colección.

El Archivo de la Guerra ocupó su papel en la movilización de la Cultura durante la Guerra Civil. El Consejo Central de Archivos, Bibliotecas y Tesoro Artístico como instrumento administrativo que tuvo la responsabilidad de asesorar al Ministerio de Instrucción Pública en esta nueva política sobre el patrimonio, se crea con una declaración de principios que ayuda a explicar el sentido que tuvo este archivo. Refiriéndose al valor del Patrimonio Cultural y sus testimonios, indica que su misión es la $\mathrm{de}^{22}$ :

transformarlos de organismos muertos que eran, enterrados bajo el polvo de una inercia secular y tan sólo inteligibles para una exigua minoría de especialistas y eruditos, en instrumentos vivos de cultura, cuya eficiencia orgánica alcance a cumplir con la elevada función social que les está encomendada, a tono con las necesidades

\footnotetext{
${ }^{21}$ Memoria del Archivo de la Guerra (copia), 1937, Archivo Intermedio Militar Pirenaico (AIMP).

${ }^{22}$ Gaceta de la República, 48, de 17 de febrero de 1937, pág. 847.
} 
Guillermo Pastor NúÑez, Henar Alonso Rodríguez, María del Carmen Rial Quintela Estrategias de archivo y orden social en la Guerra Civil española y la dictadura franquista

imperiosas de la cultura española, y de dotar al pueblo de los elementos necesarios para elevar su nivel cultural.

Fue un elemento para la propaganda y además un archivo ideológico y social, un dispositivo de conciencia de clase al margen de las agrupaciones políticas. Al igual que la alfabetización en el frente, llevada a cabo por las Milicias de la Cultura, el Archivo de la Guerra hacía partícipe a toda la sociedad del valor del archivo para una memoria que ya no era la de la Nación, sino una memoria social.

\section{Archivos exiliados}

Los miles de personas que cruzaron la frontera con Francia después de la caída de Barcelona reflejan, a través de su ejemplo, que su lugar estaba fuera del Nuevo Estado que a esas alturas ya había cobrado forma y desarrollado su aparato represor. En el nuevo orden social no había lugar para quienes se habían enfrentado a su imposición. El mismo fenómeno tendrá lugar con los archivos: el estrecho vínculo de los documentos con los individuos y sus formas de organizarse, con sus derechos y con sus responsabilidades, con sus ideas y con sus iniciativas políticas, les forzará a correr la misma suerte. Los documentos que habían sostenido a las personas o grupos políticos que se habían opuesto a los valores del Nuevo Estado o suponían una divergencia con él, quedaban también fuera del nuevo orden social. Por lo tanto, igual que los propios individuos, o eran detenidos, en este caso incautados, o debían exiliarse, sacarlos del país en su caso.

Así fue como muchos de estos archivos, o documentos que los formaban, completos o fragmentados, fueron destruidos por sus propios productores para evitar que su contenido comprometiera a miembros de su organización; otros fueron incautados por los que ocupaban el territorio ocupado para el Nuevo Estado y, por último, algunos corrieron la misma suerte que aquellos ciudadanos derrotados que pudieron optar por el exilio. Los archivos, como algo siempre vivo y mutable, se reorganizan y resignifican más allá de los límites donde se desarrolla su actividad, sus documentos "corren el incesante albur de cambiarse en otros y que todo lo afirman, lo niegan y lo confunden como una divinidad que delira", según una feliz imagen utilizada 
para exponer el efecto anarchivista en el que la reordenación perpetua destruye al mismo tiempo que compone ${ }^{23}$.

Es preciso recordar que también el Tesoro Artístico fue puesto a salvo de posibles y muy factibles daños por los bombardeos de la aviación alemana e italiana fuera de territorio español, pero su distinta naturaleza respecto a los documentos permitió que el patrimonio museístico pudiera retornar una vez finalizada la guerra. No así los documentos, cercanos siempre a sus responsables o productores, que sólo cruzaron la frontera cuando estos también tuvieron que abandonar el país. A partir de ese momento se empezará a operar en ellos una mutación sólo comprensible atendiendo a este perpetuo movimiento anarchivista ${ }^{24}$. La última documentación del gobierno republicano se librará de la incautación gracias al exilio, pero también perderá la responsabilidad que la Institución ejercía sobre ella. Del mismo modo, la última documentación del Govern de la Generalitat corre la misma suerte al cruzar la frontera francesa. Extinguidos los responsables del archivo, serán otros los custodios que tomarán el relevo y reorganizarán el archivo bajo su criterio.

De este modo, el archivo de los últimos años de la Presidencia del Gobierno de la República Española quedará bajo la responsabilidad personal de Juan Negrín López, su último presidente. Se pone en marcha su resignificación, mutando también su naturaleza y quedando convertido en un archivo privado, que desde 2013 custodia la Fundación que lleva el nombre del que fue el postrero presidente del gobierno y primer custodio personal del archivo exiliado, asentada en las Palmas de Gran Canaria, donde conviven las actividades para el fomento del conocimiento de la vida y obra de Juan Negrín, con la custodia de este archivo público.

Por su parte, será uno de los consellers del último Govern de la Generalitat de Catalunya de la Guerra Civil, Josep Tarradellas i Joan, quien lleve consigo los documentos que las difíciles condiciones del momento le permitieron transportar al cruzar la frontera hacia el exilio. En este caso, en la resignificación del archivo se

\footnotetext{
23 Andrés Maximiliano Tello, Anarchivismo. Tecnologías politicas del archivo. (Madrid: La Cebra, 2018), 13 y ss. La cita de la frase anterior se toma de esta referencia, y corresponde a Jorge Luis Borges, "La Biblioteca total", en Revista Sur 8, n 59 (8), agosto 1939.

24 Íbidem
} 
constata el interés por continuar la vida del archivo en el exilio, enriqueciendo su contenido y, en este caso, vinculándolo de forma particular a su persona y a su familia.

La instauración de la Democracia permitió el retorno a Cataluña de un archivo que lo era tanto de los últimos días del Govern de la Generalitat durante la Guerra, como del exilio y, por añadidura, también personal y de la familia Tarradellas. Unos documentos que, de este modo, reforzaban la idea del exilio y de la Generalitat restaurada, y de la propia relevancia personal de su President. Al poco tiempo de este retorno fue especialmente significativa su donación al Archivo del Monasterio de Poblet, también al margen de la gestión directa de los archivos públicos catalanes, y la voluntad del primer President de la Generalitat de la Democracia de 1978 en bautizarlo con el nombre de su hija.

Un destino muy distinto de estos archivos exiliados se forjó en el caso del archivo de la CNT-FAI. Coincidiendo con la entrada de las tropas franquistas en Barcelona, un tren cargado con las cajas que contenían el archivo de la organización libertaria salía para Ámsterdam en virtud de un acuerdo alcanzado unos meses antes con el Instituto Internacional de Historia Social de Ámsterdam. La ocupación alemana de los Países Bajos obligó a mantener los documentos a buen recaudo en París y, a continuación, para salvar el archivo de la ocupación alemana en Francia, viajaron a Londres. En 1947 el archivo de la CNT-FAI llegó por fin a su destino en Ámsterdam, pero la aparente seguridad jurídica de su situación inicial, depositado en una institución dedicada al estudio de los movimientos sociales, desembocó en un embrollo legal especialmente cuando, después de muerto el dictador en España, la situación política permitía la reconstrucción de la organización y, por lo tanto, e igual que en los ejemplos anteriores, podía facilitar la vuelta del archivo a su lugar de origen.

Paradójicamente el exilio provocó que aquellos archivos públicos afectados de personalismo vieran facilitada su vuelta, al verse ligados a la voluntad de aquellos que esgrimían los derechos de titularidad sobre ellos por el mero ejercicio de la custodia, mientras que el archivo del movimiento libertario español, que quiso afianzar su situación legal mediante un acuerdo con una institución científica, vio cuestionado su derecho de titularidad y responsabilidad sobre los fondos documentales de cuya 
organización son legítimos herederos hasta el punto de verse obligados a luchar por ellos durante los años ochenta ${ }^{25}$.

Rememorar estos tres archivos permite pensar, no sin cierta pesadumbre, que en los tres casos la organización que los produjo, y que ejercía su responsabilidad sobre ellos, perdió con el exilio sus derechos; y que en su actual situación y mediante distintos caminos, estas organizaciones, o sus legítimas o equivalentes herederas, han conseguido únicamente un reconocimiento parcial concretado en unas copias de los documentos o unos derechos simbólicos sobre ellos. Al igual que aquellos que se exiliaron ya no pudieron recobrar jamás el tiempo perdido en su país, estos archivos, como una expresión tangible de ese tiempo, no consiguen ser restituidos a sus originales productores porque estos se encuentran extraviados en una malograda línea temporal.

\section{LA PROLIFERACIÓN DOCUMENTAL PARA LA OCUPACIÓN Y EL CONTROL POSTERIOR DE LA POBLACIÓN: LOS SERVICIOS DE INFORMACIÓN MILITAR FRANQUISTAS}

\section{La monopolización de la información militar por el SIPM}

Si la información es poder, la documentación que generaban y transmitían los servicios de información militar durante la Guerra Civil era de vital importancia no solo para el desarrollo bélico del conflicto, sino también para asegurarse el control político y social de la población. La gestión de esa documentación, tanto su creación, como su distribución y su uso, ponen de manifiesto la complejidad de la estructura institucional creada por las tropas sublevadas para lograr el objetivo final de arrasar con todo el legado y la legalidad republicana y de instaurar en su lugar un Nuevo Estado.

Al inicio de la guerra, los servicios de información militar españoles apenas estaban desarrollados en comparación con los países europeos que habían participado activamente en la Primera Guerra Mundial. Más allá de las segundas secciones, de información, de los Estados Mayores del Ejército y la Marina, no existía ningún

\footnotetext{
${ }^{25}$ José Ramón Palacios, "Fotografias de un mundo nuevo en su viaje hacia la luz", en Andrés Antebi; Pablo González; Teresa Ferré y Roger Adam, Gráfica anarquista. Fotografía y revolución social 19361939 (Barcelona, Ayuntamiento, 2020).
} 
organismo a nivel central dedicado a la contrainformación. Las únicas fuentes de información a nivel internacional provenían de las agregadurías militares de las embajadas españolas en el extranjero.

Las reformas militares que se promovieron durante la República, impulsadas por el Ministro de la Guerra Manuel Azaña, aceleraron la creación de la Sección de Servicio Especial, primero al nivel de Estado Mayor Central, y después con delegaciones en las Divisiones Orgánicas, Comandancias Generales de Baleares y Canarias y Fuerzas Militares de Marruecos. Las Secciones de Servicio Especial contaban con un Departamento de Antiextremismo, dedicado a garantizar la lealtad a la legalidad republicana de los miembros del Ejército, y el Departamento de Contraespionaje, dedicado a obtener información sobre potencias extranjeras o agrupaciones políticas potencialmente hostiles. Su funcionamiento estaba amparado legalmente por la denominada Ley de Defensa de la República de 21 de octubre de 1931, y su eficacia quedó demostrada tanto durante el fallido golpe de estado del General Sanjurjo en 1932, como en la Revolución de Asturias de $1934^{26}$.

Sin embargo, no fue por ineficacia por lo que no se anticipó al golpe de estado de julio de 1936, sino por el hecho de que las Secciones de Servicio Especial del Ejército de Marruecos se pusieron desde el primer momento al servicio de los militares africanistas sublevados, y lo mismo ocurrió con las correspondientes peninsulares a medida que las tropas rebeldes avanzaban, que se fueron integrando en el recién creado Servicio de Información Militar (SIM), a instancias del General Cabanellas el 14 de septiembre de $1936^{27}$.

Pese a su voluntad centralista e integradora, el SIM no era la única agencia de información de bando sublevado, e incluso competía a la hora de desarrollar sus funciones con otras agencias de información de carácter militar, como la Comandancia Militar del Bidasoa, dirigida por el belicoso General Troncoso, la Oficina Nacional de Nacho Enea del Conde de los Andes en Biarritz, a lo que había que sumar los servicios

\footnotetext{
${ }^{26}$ Morten Heiberg y Manuel Ros Agudo, La trama oculta de la Guerra Civil. Los servicios secretos de Franco 1936-1939, Barcelona, Crítica (2006), pp. 2-7.

${ }^{27}$ Orden del presidente de la Junta de Defensa Nacional, General Cabanellas, al coronel Múgica Buhigas de organizar una oficina de espionaje y contraespionaje en el territorio dependiente de la misma. 14 de febrero de 1936. AGMAV, C.2914,27,2.
} 
de información militar de la Legión Cóndor alemana y del Cuerpo de Tropas Voluntarias italiano, así como las Secciones de Servicio Especial del Ejército de Marruecos y el Servicio de Información de la Frontera Norte de España (SIFNE).

Esta situación de pluralidad de fuentes de información que afluían al Cuartel General del Generalísimo finalizó al llegar a la Jefatura del Servicio de Información Militar José Ungría Jiménez, militar formado en las Escuelas Superiores de Guerra de Madrid y París, con formación suficiente como para poner en cuestión la efectividad del SIM como mero receptor de informaciones obtenidas por agentes de organizaciones ajenas. Además, la llegada de Ungría al Cuartel General del Generalísimo durante la conocida como Campaña de Norte, con las tomas de Bilbao, Santander y Gijón por parte de las tropas sublevadas, propició el acercamiento y la colaboración cada vez mayor con Marcelino Ulibarri y su Delegación de Estado para la Recuperación de Documentos (DERD). A partir de ese momento, la información obtenida por el SIPM sobre movimiento y situación de unidades en el frente y la búsqueda de documentos con antecedentes políticos y sociales que gestionaba la DERD, comenzaron a funcionar de manera coordinada ${ }^{28}$.

El 30 de noviembre de 1937, la segunda sección del estado mayor del Cuartel General del Generalísimo dicta una orden reservada a los Ejércitos de Operaciones modificando y ampliando los cometidos del $\mathrm{SIM}^{29}$, que pasará a denominarse desde ese momento Servicio de Información y Policía Militar (SIPM) y tendrá competencias exclusivas en lo referente al empleo de agentes de información en zona republicana y en el extranjero (con independencia de las segundas secciones del estado mayor de las unidades), en el contraespionaje y, lo que supone la mayor novedad, en la vigilancia, seguridad y orden público de la zona de vanguardia. En la práctica ello suponía, por una parte, la absorción e integración bajo el mando de Ungría, y directamente dependiente

\footnotetext{
${ }^{28}$ Gutmaro Gómez Bravo, "La información retrospectiva: ocupación del territorio y clasificación de la población en el Ejército del Norte", Sancho el Sabio. Revista de cultura e investigación vasca, $\mathrm{n}^{\circ}$ extra 1 (2018), pp. 116-118. Véase, además, Correspondencia sobre la creación del SIM del Burgos, AGMAV, C. 2914, 27, 22 que detalla cómo "formar ficheros completos de personas indeseables que hayan prestado o estén prestando actualmente su colaboración voluntaria a favor de los rojos", "ficheros completos de refugiados" e investigaciones varias sobre actividades "del gobierno rojo fuera de España" y de "simpatizantes o amigos de la España roja" por parte del SIM.

${ }^{29}$ Organización y Funcionamiento de la Jefatura y Servicios del SIPM, Cuartel General del Generalísimo, AGMAV, C. 1666, 78.
} 
del Cuartel General del Generalísimo, de todos los servicios y agencias de información previamente existentes en el bando sublevado, tanto militares como civiles; por otra parte, la asunción de funciones relacionadas de policía, seguridad y orden público, supuso una "reorientación de los servicios de información hacia una guerra de ocupación del territorio de la población" ${ }^{30}$ que favoreció el uso de esa información con fines represivos.

Según el artículo II de la Orden, la organización del SIPM se descentralizaría por Ejércitos, creándose en cada uno de ellos una Sección propia, independiente de la segunda sección de su respectivo estado mayor, de la que dependerían las Comandancias de Policía Militar de cada sector del frente, con sus grupos A de Vigilancia, B de Información y C de Explotación, sustituyendo a las antiguas unidades de Policía Secreta del frente que habían sido creadas en 1936. Esto suponía que toda la información que los agentes de cada Comandancia obtuvieran debía transmitirse a través de la Jefatura de la Sección del Servicio de Información y Policía Militar de cada Ejército a la Jefatura Central del SIPM de Ungría, garantizándose así, definitivamente, el control absoluto de la situación tanto en el frente como en las unidades desplegadas en zonas fronterizas o en retaguardia. Así se desprende de la interpretación del artículo 14 de la Orden cuando dice que

La Jefatura del SIPM y sus Secciones de Ejército se relacionarán directamente de oficio o por simple nota, con los Jefes de Cuerpo, Centros y Dependencias del Estado, en sus diversos escalones y categorías, para el envío o solicitud de datos relacionados con sus cometidos, en analogía con lo dispuesto en la orden de creación del SIM de 26 de septiembre de $1936^{31}$.

\section{La gestión documental para la ocupación y el control social. Los archivos del SIPM}

La Orden Reservada de noviembre de 1937 tuvo un desarrollo reglamentario posterior redactado por el propio José Ungría aprobado el 18 de mayo de $1938^{32}$ en el que se definía la estructura institucional del SIPM. El órgano central era la Jefatura, de

\footnotetext{
${ }^{30}$ Gutmaro Gómez Bravo, La información retrospectiva: ocupación..., 122.

${ }^{31}$ AGMAV, C. 1666,78.

32 Cuartel General del Generalísimo. Disposiciones relativas al Servicio de Información y Policía Militar (SIPM), AGMAV, C. 2951,2. Se sigue esta referencia si no se indica otra cosa.
} 
la que dependía una Secretaría Técnica para tareas burocráticas y de enlace, precisamente, con las tres secciones: $1^{a}$ Sección de Información, Propaganda y Acción en el Campo Enemigo, $2^{\text {a }}$ Sección de Contraespionaje y Antiextremismo y $3^{\text {a }}$ Sección de Información General ${ }^{33}$. A nivel periférico, y ante el crecimiento exponencial de las necesidades del servicio, se crean las Subcentrales de Irún $^{34}$ y de Cataluña del SIPM, y los Destacamentos Especiales de Cartagena, Madrid y Valencia, a las que se sumaba la Red Provincial del SIPM, formada por una red de agentes en cada provincia.

Pero si hay algo que llama poderosamente la atención del Reglamento es la profusión de normas dedicadas a la gestión de la documentación que los agentes y las distintas dependencias del SIPM generaban y transmitían en el ejercicio de sus funciones, en desarrollo de los escuetos, a la par que relevantes, artículos 8, 9 y 10 de la Orden Reservada de noviembre de 1937. Los artículos 12, 13 y 16 establecen las obligaciones de las secciones SIPM de los Ejércitos sobre recepción, análisis, interpretación, transmisión y difusión de las informaciones de los Grupos B de Información, y de envío a la Jefatura del SIPM de croquis y memorias explicativas de la organización del servicio. El artículo 20 exige la confección de un fichero de personas residentes de la zona “clasificándolos en indiferentes, sospechosas, desafectas y leales".

Los artículos 43 a 45 sobre funcionamiento de los grupos B de Información, establecen que "procederá rápidamente a la clasificación personal de los habitantes del sector, confeccionando una ficha simplificada de los mismos", con el modelo de ficha y el procedimiento que se fijan en el anexo del mismo: consistía en la asignación de una letra del abecedario junto al nombre, edad, apodo y circunstancias del sujeto reflejadas en la ficha, correspondiendo cada letra a una descripción somera de sus "culpas": antiguo izquierdista, derrotista, evadido, peligroso, moralidad dudosa,... Una vez hecho esto, se remitía copia de la ficha completa a la Jefatura del SIPM, y al ocupar un nuevo sector se mandaba la totalidad del fichero de retaguardia a la Jefatura Nacional de Seguridad Interior.

\footnotetext{
${ }^{33}$ Esta organización se reproducía en las Jefaturas de las Secciones SIPM de cada Ejército.

${ }^{34}$ La Subcentral de Irún del SIPM asumió las funciones del absorbido Servicio de Información de la Frontera Norte de España (SIFNE), e incluso siguió usando papel de color azul como hacía el SIFNE. La Sección del Servicio de Información y Policía Militar del Ejército del Sur siguió utilizando el papel amarillo característico de la Sección de Servicio Especial del Ejército de Marruecos.
} 
El artículo 59 detalla prolijamente las actividades a controlar por los agentes, como que la información se enviará en sobres preimpresos sellados dirigidos al Gobierno Militar, o que de los documentos no podían ni sacar copia ni conservarlos en su poder. Varios artículos establecen obligaciones periódicas de enviar resúmenes de actividades a la Jefatura del SIPM "sin perjuicio de cursar fuera de esos plazos aquellas notas informativas cuya importancia o urgencia así lo requieran”. En definitiva, todo un manual de gestión documental dirigido a garantizar el control total de la información dentro de la propia organización, para poder después distribuirlo a todas aquellas unidades militares u organismos del Estado que pudieran requerirlos.

El volumen de información gestionado por el SIPM durante su periodo de funcionamiento fue ingente, pues incluye tanto la documentación generada por los organismos centrales, periféricos, provinciales y locales, la de las Secciones SIPM de los Ejércitos y la de los agentes, propios y externos, es decir, los miembros de la conocida "Quinta Columna", la resistencia clandestina nacional en la retaguardia republicana, principalmente en Madrid y Barcelona, posteriormente asimilados. Estos grupos, en principio espontáneos y autónomos, fueron finalmente controlados por la organización de Ungría, de tal manera que, al finalizar la guerra, a los integrantes de los grupos de información de la Quinta Columna se les conceden recompensas como agentes del SIPM $^{35}$.

En octubre de 1939 el Alto Estado Mayor emite una orden de disolución del Servicio de Información y Policía Militar, por la que se crea la Comisión de Desmovilización, que se completa con una Orden Particular de esa Comisión de 9 de enero de 1940 que dedica, de nuevo, buena parte de su articulado a regular el destino de la documentación y los archivos del $\mathrm{SIPM}^{36}$.

El $4^{\mathrm{o}}$ negociado de la Comisión tenía a cargo la información a jueces, tramitación de incidencias y formación de inventarios. Los negociados $1^{\circ}, 2^{\circ}$ y $3^{\circ}$ se dedicaron respectivamente a la revisión de los expedientes, de los ficheros y de los

\footnotetext{
${ }^{35}$ Para el estudio de la Quinta Columna, Carlos Píriz González, "En campo enemigo: La Quinta Columna en la Guerra Civil Española (Tesis doctoral, Universidad de Salamanca, 2019)

${ }^{36}$ Cuenta, minuta y copia de la Orden Particular $n^{\circ} 1$ de la Jefatura del Servicio de Información y Policía Militar (SIPM) de la Comisión de Desmovilización del SIPM, AGMAV, C. 2962, 18.
} 
documentos sin clasificar generados por el SIPM. Los jefes los negociados $1^{\circ}, 2^{\circ}$ y $4^{o}$ fueron los encargados de clasificar y decidir el destino de los documentos conforme a las normas del artículo IV de la Orden Particular. La clasificación numérica era la siguiente:

1- Documentos de interés histórico.

2- Documentos de interés militar actualidad.

3- Documentos de interés judicial.

4- Documentos de interés policial relativos a personal civil.

5- Documentos de interés policial relativos a personal militar.

6- Documentos de interés relativos a servicios de espionaje rojo.

7- Documentos de interés relativos a servicios de espionaje extranjero.

Mientras tanto, al jefe del Negociado $3^{\circ}$ se le asignó la documentación pendiente de clasificación como Expedientes para revisión, Ficheros para revisión o Varios, remitiendo por triplicado el inventario de los mismos a los negociados $1^{\circ}, 2^{\circ}$ y $3^{\circ}$, para que procediesen a encarpetarla y formar legajos en unión de la documentación organizada por ellos mismos, a fin de remitir:

- Lo clasificado bajo el número 1, al Archivo Histórico Militar.

- Lo clasificado bajo los números 2 y 5, junto a la Cartografía, a las segundas secciones de los estados mayores del Cuerpo de Ejército.

- Lo clasificado bajo los números 3 y 4, a la Jefatura de Policía de la capital de provincia donde resida la cabecera de la Región Militar.

- Lo clasificado con los números 6 y 7, a la Tercera Sección del Alto Estado Mayor.

Como consecuencia, los archivos del SIPM quedaron repartidos en dos grandes grupos. Uno está constituido por los fondos que fueron a parar a los archivos militares, ya sea al Servicio Histórico Militar $(\mathrm{SHM})^{37}$ y a las Regiones Militares ${ }^{38}$, o al Estado

\footnotetext{
${ }^{37}$ Sobre la organización archivística del SHM por el Archivo General Militar de Ávila, ver: Henar Alonso Rodríguez, Organización de los fondos del Archivo General Militar de Ávila, Boletín del Sistema Archivistico de Defensa, $\mathrm{n}^{\circ} 22$ (2012), pp. 3-12.

${ }^{38}$ Sobre la relación entre los fondos documentales del Archivo General Militar de Ávila y los Archivos Intermedios Militares (sucesores de los Regionales), ver: María del Carmen Rial Quintela, Los fondos
} 
Mayor del Ejército, que se encuentran ya integrados en el Sistema Archivístico de Defensa, y por tanto disponibles para su consulta. Otros, fueron asignados al Alto Estado Mayor, que los derivó al Servicio Central de Documentación (SEDEC) y posteriormente a sus organismos sucesores, el Centro Superior de Estudios de la Defensa (CESID) y el actual Centro Nacional de Inteligencia (CNI), manteniéndolos así desconectados del Sistema Archivístico de la Administración General del Estado. Finalmente, otro grupo se recibió en las Jefaturas de Policía y, por lo tanto, pasaron a la Dirección General de Seguridad y, actualmente, están integrados en el Sistema Archivístico del Ministerio del Interior, cuya estricta normativa de acceso da prioridad absoluta a la protección de datos personales.

De esta manera, actualmente sólo es posible acceder a una tercera parte de la documentación de esos Servicios de Información Militar, cuyo interés reside en que actuaron no sólo como fuentes de información para tomar decisiones estrictamente bélicas durante la Guerra Civil, sino también para las funciones represivas de las jurisdicciones especiales que funcionaron durante y después del conflicto armado.

\section{EI uso postrero del fichero del SIPM. EI control social sobre los militares}

Entre 2018 y 2019 ingresaron en el Archivo General Militar de Ávila el Fichero (alrededor de 170.000 fichas de información personal) y los Expedientes de Información Personal (unas 245 cajas, correspondientes a 1265 legajos), generados tanto por el Servicio de Información y Policía Militar franquista, como posteriormente por la Segunda Sección del Estado Mayor del Estado Mayor Central del Ejército ${ }^{39}$. La entrega la realizó el Estado Mayor del Ejército a través del Consejo Superior del Ejército ${ }^{40}$, cuyo Tercer Negociado se había encargado de la custodia y gestión de los ficheros y archivo de información de la denominada "zona roja", de los citados generados por el

documentales del franquismo en los archivos militares, La alargada sombra del franquismo (Granada: Comares, 2019), 397-418.

39 Dos grupos documentales originados por los mismos organismos productores ya habían ingresado previamente. Un pequeño grupo de 11 cajas ingresó inserto en el conocido "Archivo de la Guerra de Liberación", incluido dentro de la documentación de la "Zona Nacional". El segundo grupo ingresó desde el Servicio Histórico Militar en 1994, y consiste en 193 cajas que el SIPM remitió durante su desmovilización al Estado Mayor del Ejército, en cuyas instalaciones permanecieron hasta 1981 que se transfirieron al entonces todavía existente Servicio Histórico Militar.

${ }^{40}$ En torno a 1960 el Consejo Superior del Ejército aparece como $4^{\text {a }}$ Sección de la Subsecretaría del Ministerio del Ejército, organizado en una Secretaría y tres Negociados. 
SIM/SIPM y la segunda sección del Estado Mayor del Ejército, y de los Informes reservados del Consejo Supremo de Justicia Militar y la Asesoría Jurídica del Ejército.

Además, el Consejo Superior del Ejército entregó su propia documentación datada entre 1939 y 1987, incluyendo los ficheros propios que elaboró dicho organismo como resultado de su participación en los dos procedimientos de depuración de responsabilidades político-sociales del personal militar tras el conflicto armado: el derivado de la Ley de 1 de marzo de 1940 de represión de los delitos de masonería y comunismo, y el derivado de la Ley de 12 de julio de 1940 de revisión de escalas.

El Consejo Superior del Ejército se había constituido como órgano consultivo del Ministerio del Ejército por Orden del mismo de 18 de abril de $1940^{41}$, pero jugó un destacado rol en la represión y control social de los militares en las dos vertientes citadas. El 3 de julio de $1945^{42}$ se confirman las reglas que para su actuación había establecido el artículo 11 de la Ley de 1 de marzo de 1940 sobre represión de la masonería y el comunismo:

cuando se trate de militares profesionales de categoría igual o superior al de oficial de los Ejércitos de Tierra, Mar o Aire, serán competentes los Tribunales de Honor, constituidos y funcionando conforme a las normas de sus respectivos Institutos. Las actas de dichos Tribunales serán elevadas al Consejo Superior del Ejército para su aprobación a los efectos, no sólo de mantener la pureza del procedimiento, sino también la necesaria unidad de criterio en cuanto al fondo, pudiendo por este motivo someter los fallos a revisión de un Tribunal mixto constituido por representaciones de los Ejércitos de Tierra, Mar y Aire. A los fines de este artículo el Consejo Superior del Ejército funcionará ampliado con un representante del de Mar y otro del de Aire.

Para el resto del personal civil era competente el Tribunal Especial de Represión de la Masonería y el Comunismo (TERMC), constituido formalmente el 4 de junio bajo la presidencia de Marcelino de Ulibarri, el jefe del Servicio de Recuperación de Documentos, organismo cuya Sección de Servicios Especiales quedó afecta al TERMC como Oficina Auxiliar por custodiar los documentos incautados a los masones desde la

\footnotetext{
41 Recuperado el 11-06-2020 desde: https:/www.boe.es/datos/pdfs/BOE/1940/116/A02826-02827.pdf . Existe una orden previa al respecto de 9 de noviembre de 1939. Recuperado el 11-06-2020 desde: https://www.boe.es/datos/pdfs/BOE/1939/321/A06454-06454.pdf

42 Recuperado el 11-06-2020 desde: https://www.boe.es/datos/pdfs/BOE/1945/200/A00441-00441.pdf
} 
creación de la Delegación de Asuntos Especiales ${ }^{43}$. Su conjunto documental era conocido como el "Archivo Masónico", y su función era la de aportar los documentos, informes y certificaciones a partir del material requisado a las logias tanto para el TERMC como para los Tribunales de Honor, principalmente, a fin de comprobar la veracidad de las retractaciones antes de elevar sus conclusiones al Consejo Superior del Ejército. Como el TERMC, los Tribunales de Honor ${ }^{44}$ jugaron un papel en la represión política y el control social, en concreto, de los oficiales de los Ejércitos.

Otra vertiente del control social sobre los militares se ejerció de modo más sutil, emulando los procesos de depuración que en el ámbito civil facilitaba la Ley de Responsabilidades Políticas. A fin de asegurar la pureza ideológica de los integrantes del propio Ejército Nacional, hubo una depuración específica que consistió en establecer procedimientos para decretar su baja del Ejército o su degradación o postergación en los escalafones. A las filas del Ejército sublevado se habían incorporado muchos de los afectados por la "Ley Azaña" de reforma del Ejército que tan poco agradó al estamento militar, y no todos tenían las aptitudes requeridas por "el alzamiento nacional en defensa de la Patria".

La Ley de escalas de 12 de Julio de 1940, "por la que se faculta a los Ministros de Tierra, Mar y Aire para pasar a situación de reserva a los Generales, a las escalas complementarias o similares o situación de retirados, a Jefes, oficiales y asimilados, y a situación de retirados a los Suboficiales y Cuerpo Auxiliar Subalterno del Ejército en determinadas condiciones", supuso la culminación práctica de un procedimiento de depuración de personal militar considerado "inadecuado" que se había iniciado con el Decreto núm. 100 de 12 de diciembre de $1936^{45}$, que preveía la forma en que las Juntas Superiores de Guerra y Marina propondrían la baja del personal sin aptitudes para ejercer el mando, pero retrasando su instrucción y justificación a la finalización de la guerra.

\footnotetext{
${ }^{43}$ Antonio González Quintana, Fuentes para ... 479-508

${ }^{44}$ Los Tribunales de Honor se crean por Ley de 27 de septiembre de 1940, y en 22 de octubre de ese mismo año se dictan instrucciones para la tramitación de los casos en que la Ley de 1 de marzo sea de aplicación al personal militar, quedando sujetos a la obligación de pasar por el Consejo Superior del Ejército. Se aprueban también unas Instrucciones Reservadas a las autoridades regionales para la tramitación de esos casos, de 7 de agosto de 1941.

45 Recuperado el 11-06-2020 desde: https://www.boe.es/datos/pdfs/BOE/1936/057/A00398-00398.pdf
} 
Guillermo Pastor Núñez, Henar Alonso Rodríguez, María del Carmen Rial Quintela Estrategias de archivo y orden social en la Guerra Civil española y la dictadura franquista

En 1940, por tanto, bajo la apariencia de un procedimiento sobre las liquidaciones de guerra y las consolidaciones de derecho a pensión por el tiempo de servicio prestado durante el conflicto armado en el Ejército Nacional, en realidad lo que se facilitó fue la depuración del personal militar que por diversas circunstancias no pudo, o no quiso (por haber sido movilizado por el Ejército Popular, por haber estado prisionero o refugiado, o por otras circunstancias), servir todo el tiempo en el bando ganador. El perjuicio para el depurado se traducía no solo en una reducción de sus haberes económicos, sino también en un posible pase forzoso a reserva o retiro.

\section{LA NATURALEZA DE LOS SUMARÍSIMOS Y LAS ESTRATEGIAS ARCHIVÍSTICAS DE LA DICTADURA}

\section{La perpetuación de la jurisdicción de Guerra hasta 1963 como control social}

Con el término "sumarísimos" se designa al conjunto de expedientes sustanciados por los juzgados y tribunales militares en el territorio sublevado a partir del 18 de julio de 1936, que se extendieron geográficamente durante la Guerra Civil con cada victoria del bando nacionalista, y que continuaron durante la dictadura hasta la instauración de la jurisdicción de Orden Público en diciembre de 1963. Estos expedientes constituyen aproximadamente dos tercios del volumen total estimado de 15.000 metros lineales ${ }^{46}$ de documentación judicial militar, cifra que dibuja claramente el desmesurado alcance que tuvieron los sumarísimos, tanto por haber afectado al conjunto de la población, como por su perpetuación temporal más allá de la Guerra Civil.

La denominación se debe a que las reglas procesales de disminución de garantías de defensa denominadas "procedimiento sumarísimo" que el Código de Justicia Militar (en adelante, CJM) de 1890 limitaba a "los reos de flagrante delito militar, que tengan señalada pena de muerte o perpetua", pasaron a ser aplicadas en todos los casos, a “todos los autores, cómplices o encubridores de cuentos delitos se previenen contra el orden público en los Códigos Penal Ordinario, de Justicia Militar y Ley de Julio de 1933”.

\footnotetext{
${ }^{46}$ Manuel Melgar Camarzana y Silvia Alicia López Wehrly, Los archivos militares: qué son y cómo se tratan (Gijón: Trea, 2010), pág. 114.
} 
Con esta previsión del bando firmado por el general Franco el 18 de julio de 1936 declarando el estado de guerra, se estrenaba la jurisdicción militar preferente y la extensión del procedimiento sumarísimo a cualquier comportamiento político o social que pudiese entorpecer o contravenir el objetivo de la sublevación y las órdenes de sus dirigentes, que además adoptaban las facultades del poder legislativo y ejecutivo de dictar normativa. Respecto a las intenciones de control social por parte de los integrantes de la sublevación, fue más clara la redacción del bando de declaración del estado de guerra del territorio de la Comandancia Militar de La Coruña, fechado el 20 de julio de 1936, ya que se refería a "todos los hechos delictivos de origen o fin político social" 47 .

Desde 1936 hasta 1963 estuvo vigente una jurisdicción de Guerra, y no una jurisdicción militar ${ }^{48}$, como habían sido la contemplada en el CJM de 1890 o en el corpus normativo vigente durante la República. Tras el propósito inicial de utilizar los sumarísimos para someter la resistencia a las fuerzas militares insurrectas, el devenir del conflicto abierto condujo a las autoridades nacionales a adaptar su uso al servicio de sus ansias de victoria total, y al término de la guerra, al sometimiento del enemigo. El año 1947 cerró el periodo durante el cual la dictadura colmó el Boletín Oficial del Estado con la amenaza constante de los consejos de guerra y de otras jurisdicciones represoras creadas ad hoc, pero eso no significó el retorno de facultades a la jurisdicción ordinaria. Una de las incontables reseñas sobre consejos de guerra celebrados en España que recibió el Foreign Office británico resumía la situación ${ }^{49}$ :

A partir de nuestra observación de juicios recientes, parece claro que las autoridades militares no tienen intención de declinar su función en favor de los tribunales civiles en casos de naturaleza politica. La Ley de 3 de mayo no obliga en realidad a la transferencia de estos asuntos desde la jurisdicción militar a la civil, sino que garantiza que aquella autoridad discrecionalmente decida en cada caso. La autoridad militar continúa ejerciendo los poderes represivos

\footnotetext{
${ }^{47}$ Un ejemplar fue incorporado al Sumarísimo núm. 413/1936 contra los Generales Salcedo y Caridad, Archivo Intermedio Militar Noroeste (AIMNO), Fondo judicial de Coruña, C5.

48 Juan José del Águila Torres, "La represión política a través de la jurisdicción de guerra y sucesivas jurisdicciones especiales del franquismo", Hispania Nova, no 1 Extraordinario, (2015), pág. 213.

${ }^{49}$ The National Archives (TNA), FO371/67905,Z8141. Traducción propia desde el inglés original.
} 
que adquirieron cuando el General Franco proclamó la ley marcial en 1936.

La mencionada como "Ley de 3 de mayo" era en realidad el Decreto-Ley de 18 de abril de 1947 (publicado en el BOE del 3 de mayo, y rectificado en el del día 6), titulado "sobre represión de los delitos de bandidaje y terrorismo". Su artículo noveno mantenía el procedimiento sumarísimo y la competencia preferente de la jurisdicción militar, y su parte expositiva declamaba "la estabilidad de la situación política" salvo por lo relativo a "las más graves formas de la delincuencia terrorista y del bandolerismo", esto es, salvo por la resistencia antifranquista cuyo máximo exponente era la guerrilla armada organizada. En el interior de la España de 1947, el orden público y social se encontraba en una situación de:

lucha casi residual entre el poderoso aparato represivo franquista y un heterogéneo, disperso y fragmentado movimiento guerrillero, apoyado por una fracción de la población civil. Movimiento que, sin llegar a poner en peligro en ningún momento la existencia misma de la dictadura, sí fue para ésta una amenaza real en cuanto a su estabilidad en el interior y su credibilidad en el exterior ${ }^{50}$.

Desde que durante la Guerra Civil se dieran los primeros casos de huidos, las fuerzas represoras franquistas mantuvieron la estrategia de utilizar a las personas implicadas en las redes de apoyo a los guerrilleros para cercar a éstos, especialmente a partir de que la resistencia armada empezó a ser organizada por los combatientes republicanos que escaparon a la caída del frente norte. Así se refleja en las medidas aprobadas en 1938 por el Cuartel General del Generalísimo a propuesta del SIPM ${ }^{51}$ :

Apruebo el ofrecimiento de premios en metálico a las personas que por señalar a nuestras fuerzas la presencia y situación de guerrilleros faciliten la captura de los mismos, en cantidad proporcionada a la importancia del servicio prestado.

Merece igualmente mi aprobación el ofrecimiento de libertad a los presos gubernativos que sean familiares próximos de aquellas personas que entreguen o consigan la captura de algún guerrillero, o la atenuación de la condena en otros casos.

\footnotetext{
${ }^{50}$ Mercedes Yusta Rodrigo, "Una guerra que no dice su nombre. Los usos de la violencia en el contexto de la guerrilla antifranquista (1939-1953)", Historia Social, nº 61 (2008), pág. 109.

${ }^{51}$ Correspondencia sobre represión de actividades de guerrilleros, 1938. AGMAV, C. 2918, 30.
} 
Si la jurisdicción castrense hubiese llevado a la práctica lo previsto en el artículo noveno del Decreto-ley de 18 de abril de 1947, esto es, si hubiese adoptado sistemáticamente la postura de inhibirse ante los actos de menor gravedad como podían ser los de enlace y apoyo a la guerrilla (actividades que iban desde la transmisión de mensajes sobre planes de sabotaje o ataque, hasta facilitar cobijo y comida, pasando por la distribución de prensa y folletos clandestinos) habría renunciado a un dispositivo enormemente eficaz para acabar con los elementos armados más relevantes.

La disposición de información de primera mano, sin la intermediación de la justicia ordinaria, lograda a partir de las personas que formaban el tejido logístico, de comunicación y de cuidados de la guerrilla armada, fue la mejor herramienta para represaliar las actuaciones de mayor calado político. Cualquier declaración, delación o documento incautado podían conducir al escondite de las figuras dirigentes de la guerrilla, y para obtenerlos no se dudó en modular la gravedad de las condenas militares. El resultado de imponer condenas por hechos leves en vía militar era valorado por la Embajada británica en Madrid como "tiranía legalizada",52, retratando que precisamente en estos casos, los juzgados y tribunales militares intervenían radicalmente en el orden social para imponer su nuevo orden público ${ }^{53}$.

\section{La ruptura de la naturaleza de las causas militares en 1936: los sumarísimos}

La ley de jurisdicciones de 1906 traspasó a la jurisdicción militar los delitos contra la seguridad del Estado y la injuria contra el Ejército o la Marina, lo que supuso una ampliación desproporcionada del ámbito penal militar ${ }^{54}$. El Ejército utilizó esta normativa para consolidar su posición social, pero incluso así, fue limitado el alcance que las causas militares tuvieron sobre la vida cotidiana durante el periodo que termina el 14 de abril de 1931. La jurisdicción militar, por lo tanto, llegaba a autolimitarse, ya

\footnotetext{
52 TNA, FO371/67905,Z8384.

${ }^{53}$ Sobre el papel de la Auditoría de Guerra del Ejército de Ocupación en el control social, ver: Alejandro Pérez-Olivares García, "La victoria bajo control: ocupación, orden público y orden social del Madrid franquista (1936-1948)" (Tesis doctoral, Universidad Complutense de Madrid, 2017).

54 Ernesto Pedraz Penalva, "La Administración de Justicia durante la Guerra Civil en la España Nacional", Justicia en guerra: Jornadas sobre la administración de justicia durante la Guerra Civil Española, Madrid, Ministerio de Cultura, 1990, pág. 324.
} 
que los jueces militares finalizaban frecuentemente su instrucción con autos de sobreseimiento o declaraciones de no responsabilidad, y tampoco era extraño que se inhibiesen en favor de la justicia ordinaria.

El examen de los inventarios existentes refiere sobre todo hechos relacionados con la vida militar (desobediencias y abusos de autoridad, protestas en cuarteles, desórdenes públicos...) o directamente con operaciones militares. Además, las personas procesadas tenían siempre algún vínculo con los Ejércitos (además de tropa y mandos, mozos de reemplazo, trabajadores y trabajadoras de la Administración militar...), siendo frecuentemente oficiales y jefes militares. Cuando se juzgaba a un grupo de personas por los unos mismos hechos, era habitual condenar a una o dos personas como medida de amedrentamiento del resto, y a menudo se concedía el indulto (total o parcial) por las penas de prisión ${ }^{55}$.

Los periodos de declaración de estado de excepción o guerra y la revolución (o revoluciones) de 1934 fueron las excepciones que durante la Segunda República llevaron ante la jurisdicción militar a personas "paisanas", entendiendo como tales a todas aquellas que no tenían ningún vínculo legal o administrativo con los Ejércitos. La instrucción de las causas militares por participar en "los sucesos revolucionarios" de 1934 se caracterizó por seguir el procedimiento sumarísimo tal y como venía regulado en el CJM de 1890, y la proclamación del estado de guerra no incluyó modificación alguna al respecto. La utilización de la ley marcial contra personas paisanas en estos casos tuvo como única finalidad que el orden establecido recuperase el control de la situación ${ }^{56}$.

Por tanto, los expedientes formados por los tribunales militares hasta la sublevación militar del 18 de julio de 1936 ofrecen el testimonio de una jurisdicción militar actuando dentro del sistema político establecido, ya que fueron instruidas por los juzgados militares previamente existentes, los delitos investigados apenas se apartan de

\footnotetext{
${ }^{55} \mathrm{El}$ consejo de guerra por la sublevación de Jaca, por ejemplo, acaba con la ejecución de dos oficiales del Ejército con ánimo ejemplarizante.

${ }^{56}$ La intención declarada en 1934 era restablecer "todas las leyes de la República", y por ello el ejercicio de la jurisdicción militar contra "la rebeldía, que ha logrado perturbar el orden público", resultó en sobreseimientos o penas de prisión, y únicamente 2 de las condenas a muerte impuestas fueron ejecutadas. Recuperado el 09-06-2020 desde: https://www.boe.es/datos/pdfs/BOE/1934/280/A0019400194.pdf
} 
la vida ordinaria de las unidades militares, la mayoría de expedientes se abrían contra militares, su resultado punitivo fue casi siempre moderado ,y se aplicaron siempre el CJM de 1890 y el resto de la normativa aprobada por los órganos ordinarios del Estado. Incluso cuando tras la revolución de 1934 se decidió ampliar el ámbito de los tribunales militares para facilitar el control del orden público, se usaron las figuras normativas constitucionalmente previstas ${ }^{57}$ :

Por Ley de 17 de julio de 1935 se reorganizó la justicia militar y se anuló parte del articulado de los decretos de 11 de mayo (limitación de la competencia de la jurisdicción castrense a hechos o delitos esencialmente militares) y 2 de junio de 1931, sobre todo en lo relativo a la intervención en materia judicial de las autoridades militares.

Por el contrario, los sumarísimos que arrancan en la sublevación del 18 de julio de 1936 fueron instruidos por una multitud de juzgados militares "eventuales" y "especiales" creados sobre la marcha por los nacionalistas por necesidad bélica o interés ideológico. Además, la jurisdicción ordinaria quedó vaciada de funciones en favor de la jurisdicción de Guerra, que "no sólo se amplió su esfera cognitiva mediante el incremento de las infracciones criminales sino también a través de la desnaturalización de las mismas" al asimilarse al delito de rebelión militar hechos "incalificables como delitos militares y, ni siquiera, significativos de oposición política" ${ }^{, 58}$.

A mayores, el procedimiento sumarísimo que se aplicó fue el establecido por autoridades militares sin más legitimación para el dictado de normas que la de las armas, y de facto supuso la anulación de cualquier garantía procesal y posibilidad de defensa. A pesar de lo que puede sugerir su etimología, el procedimiento sumarísimo a partir del 18 de julio de 1936 no se limitaba simplemente a facilitar la celeridad de la tramitación y la acumulación de actos procesales.

La aplicación de las reglas de tramitación previstas en el artículo 653 del CJM de 1890 a todos los delitos, unida a la regulación añadida por los bandos de guerra y por los Decretos núm. 64, 79 o 55 de 1936, tuvo como resultado que se decretaba la prisión

\footnotetext{
57 Eduardo González Calleja, "Construcción y defensa del Estado en la Segunda República Española (1931-1936)”, Crónica Jurídica Hispalense: revista de la Facultad de Derecho, nº 13 (2015), pág. 138.

${ }^{58}$ Ernesto Pedraz Penalva, "La Administración de Justicia durante... op. cit., pp. 365.
} 
de toda persona procesada y prácticamente no existía opción de interponer recursos ni de contar con una defensa profesional. Además, fue excepcional la práctica de pruebas ante el consejo de guerra, lo que implicaba "una manifiesta infracción del principio de inmediación en la práctica de la prueba y la correspondiente indefensión de los acusados" $" 59$.

Bajo la estructura judicial formal de los sumarísimos, la dictadura dio cobertura al control de los comportamientos sociales, públicos y privados, facilitando un cauce estatalizado a la incitación de delaciones y confesiones, e insertando en el espacio formal penal todas aquellas informaciones ideológicas que la trastienda del Nuevo Estado había recogido, en especial, mediante las diligencias de unión a las actuaciones de informes de conducta (de la Guardia Civil, Falange, párrocos, alcaldes,... pero también del SIPM o de la DERD). De esa relación entre la actuación pretendidamente jurisdiccional y la investigación policial dio cuenta a finales de $1938^{60}$ :

La Jefatura del SIPM me hace patente los perjuicios que se derivan de que su Agentes que intervienen activamente, pero naturalmente en forma secreta en el descubrimiento de delitos contra la seguridad de la Patria sean obligados a hacer actos de presencia ante los Tribunales de Justicia Civiles o Militares para actos que se deriven de la instrucción de los procedimientos o diligencias, descubriendo asi su condición e inhabilitándolas para servicios ulteriores (...) autorizo a que cuando los Agentes del SIPM tengan que hacer manifestaciones ante los Tribunales Militares o Civiles lo hagan por medio de informe.

Tanto las denominaciones de las autoridades intervinientes en cada sumarísimo (Defensor, Fiscal, Auditor, Juez) como las de los trámites y documentos que se iban generando, facilitaron al régimen franquista presentar cada sumarísimo como el resultado de una actividad jurisdiccional formalizada, y por ello, revestida de cierto grado de justicia. Incluso el hecho de que la dictadura concediese indultos y reducciones de condena, a aplicar de modo particular tras el examen individual del fallo dictado contra cada persona, venía a reforzar la versión oficial de que había existido una culpa penal individual, y no una represión ideológica revestida de apariencia judicial.

\footnotetext{
${ }^{59}$ Carlos Jiménez Villarejo, "La destrucción del orden republicano (apuntes jurídicos)". Hispania Nova. No 7, (2007), pág. 20.

${ }^{60}$ AGMAV, C. 18005, 39.
} 


\section{Estrategias archivísticas sobre los sumarísimos}

Los regímenes políticos que se sucedieron desde finales del siglo XIX hasta 1936 dieron a sus causas militares el corto recorrido que les era consustancial, de modo que, tras dictarse y ejecutarse la sentencia, su custodia pasaba al Archivo de la Región Militar correspondiente, que era el encargado de remitirlas al Archivo General Militar. También estaba establecida la organización a aplicar a la documentación de la justicia militar, tanto en lo relativo a su clasificación, como a su ordenación e instalación ${ }^{61}$ :

"La $4^{a}$ sección (causas) no tiene divisiones, y comprende los procedimientos, sumarias y expedientes administrativos, informativos y gubernativos en folio, los cuales llevarán una numeración correlativa".

Así, el trámite de archivo dotó a las causas militares anteriores al 18 de julio de 1936 de un nivel de recato incluso mayor del que les correspondía por naturaleza, al intercalarlas con otro tipo de actuaciones de menor calado político y social ${ }^{62}$. El retiro natural de las causas militares de esta época vino exigido por la duración corta de sus efectos jurídicos, y la actuación archivística prevista acentuaba su declive espontáneo. Las causas militares, una vez cerradas y pasadas al archivo, quedaban aletargadas para siempre.

Dentro de las estrategias archivísticas franquistas, se incluyó revivir algunas de estas causas militares a fin de negar la actuación judicial republicana, como parte de la destrucción del orden político y social republicano que requería montar el Nuevo Estado. En especial, las causas militares contra las personas que habían tomado parte en la revolución de 1934 fueron reutilizadas por la dictadura como pruebas de cargo en sus sumarísimos, en la Causa General o en los expedientes de responsabilidades políticas. Las causas abiertas en sentido opuesto, a consecuencia de la denuncia de maltratos o excesos en las actuaciones de las fuerzas militares, fueron archivadas sin más trámites.

\footnotetext{
${ }^{61}$ Real orden de 1 de septiembre de 1898 por la que se aprueba el Reglamento Provisional para el régimen y servicio de los archivos, especialmente su artículo 13. Recuperado el 09-06-2020 desde: http://bibliotecavirtualdefensa.es/BVMDefensa/i18n/catalogo_imagenes/grupo.cmd?path=98453

62 Esta "Sección" incluía todas las tipologías ordinarias de la justicia militar de la época: penales como causas (ordinarias y sumarísimas), diligencias previas y expedientes judiciales por falta, y también no penales como expedientes abintestato, de accidente laboral, de solvencia, administrativos o informativos.
} 
Las causas seguidas ante la justicia popular durante la Guerra Civil fueron también reutilizadas como fundamento probatorio de la Causa General cuando de algún modo incluían información sobre actuaciones contrarias a la sublevación. Si el contenido no era de ese tipo, y la precipitación de acciones bélicas había dejado a medias su instrucción, las causas populares acabaron siendo digeridas por la jurisdicción de Guerra e incorporándose al grupo documental de sumarísimos correspondiente ${ }^{63}$.

Respecto a los sumarísimos, se aplicaron las estrategias documentales necesarias para responder a las prioridades del régimen franquista, siendo la principal de ellas el mantenerlos próximos a los organismos encargados de realizar los trámites derivados de la política penitenciaria de la dictadura, de por sí parte de la política de represión, como añadir lo relativo a las conmutaciones o poner al día cualquier otra información sobre ejecución de condena (traslados del preso, puesta en libertad vigilada, en libertad definitiva... $)^{64}$.

Esta instrumentalización se reflejó tanto en cada sumarísimo en particular, como en los conjuntos formados por ellos. Como consecuencia, en algunos casos, como el de la $8^{\mathrm{a}}$ Región Militar, los sumarísimos se mantuvieron atomizados en su respectiva demarcación (Comandancias Militares de Santiago, Vigo y Ferrol y los cuatro Gobiernos Militares). En otros, como en la $4^{\text {a }}$ Región Militar, se reunieron los sumarísimos de toda la demarcación en Barcelona, a disposición de la Auditoría de Guerra.

Un caso, especialmente gráfico, acerca de las diferentes soluciones que se dieron para asegurar el servicio penitenciario de los sumarísimos lo encontramos en los correspondientes a las provincias de Burgos, Álava y Palencia, ya que el examen de las diferentes numeraciones de las portadas de los sumarísimos revela que fueron reunidas

\footnotetext{
${ }^{63}$ Por ejemplo, el sumario núm. 85 del Juzgado Especial de Santander afecto al Tribunal Popular, por auxilio a la rebelión, cuya instrucción fue interrumpida el 7 de agosto de 1937, y que es retomada únicamente a efectos de nombramiento de juez militar y secretario y de decretar su archivo en marzo de 1943, reformulando previamente su sentido mediante el añadido de una nueva portada indicando "Diligencias previas en averiguación de la responsabilidad que pudieran tener las presentes actuaciones instruidas por los rojos". AIMNO, Fondo judicial de Santander, S12456.

${ }^{64}$ Esta continua utilización se realizaba, en el vocabulario de los juzgados y Auditorías, mediante el "desarchivado" del sumarísimo, que consistían en su localización dentro del ingente volumen de documentación, su retirada del legajo correspondiente y, o bien la emisión del certificado o testimonio, o bien la remisión del propio expediente.
} 
en un único conjunto, e instaladas intercaladas unas con las otras, siguiendo todos los expedientes una única numeración correlativa. Sin duda, el fulminante dominio de la sublevación en estos territorios y su proximidad a un frente de combate que duró un año más fueron factores que impulsaron en un primer momento la centralización de los sumarísimos en el archivo de la Auditoría de Guerra de la $6^{\mathrm{a}}$ Región Militar, que los clasificó en su "Primera Sección. Procedimientos criminales". Los sumarísimos fueron posteriormente separados (no sin errores en el proceso) y reintegrados al territorio de procedencia para facilitar la aplicación de la política penitenciaria de posguerra.

Los documentos correspondientes a todas estas actuaciones se fueron añadiendo a cada sumarísimo conforme los usos burocráticos de cada dependencia militar. En casi todos los casos, se incorporaban al final del expediente cosido, utilizando grapas u otros elementos de sujeción similares. Así puede observarse tanto en el caso de los sumarísimos archivados en las Regiones $6^{\mathrm{a}}$ (provincias en torno a la de Burgos), $7^{\mathrm{a}}$ (resto de Castilla y León y Asturias) y $8^{\text {a }}$ (provincias de Galicia), como en el caso de los sumarísimos de la zona centro de la Península. Sin embargo, en los sumarísimos de la Auditoría de Guerra de Cataluña, las hojas correspondientes a estos documentos se colocaban sueltos al inicio del expediente cosido, tras la portada o entre las primeras páginas del sumarísimo ${ }^{65}$.

La localización del sumarísimo que interesaba se complicaba no sólo ante el volumen documental, sino también por la complejidad que los caracterizaba. Las anomalías de tramitación y procesamiento que se habían aplicado para facilitar la represión política y el control social se habían plasmado documentalmente en expedientes relativos en ocasiones a decenas de personas. Por ello, los juzgados y auditorías de guerra se afanaron en formar ficheros-índice onomásticos alfabéticamente ordenados, con una ficha para cada persona en la que se hacía referencia a la numeración del legajo en que se había instalado el sumarísimo en el que se habían visto implicadas. Lo habitual fue que se hiciese ficha únicamente de las personas procesadas, o incluso sólo de las incluidas en las sentencias, por lo que no podían localizarse en los ficheros a muchas de las personas represaliadas o víctimas de la violencia política, como

\footnotetext{
${ }^{65}$ Para la localización actual de los sumarísimos de cada provincia, puede consultarse la web de Memoria Histórica del Ministerio de Defensa. Recuperado el 14-06-2020 desde: https://www.defensa.gob.es/memoriahistorica/a_militares_guia.html
} 
aquellas a quienes se aplicó la ley de fugas, o aquellas que fueron detenidas e investigadas hasta su sobreseimiento por cualquier motivo.

A pesar de las diferencias de naturaleza con las causas militares, lo que sí se aplicó de forma uniforme por la dictadura franquista sobre cada uno de los grupos documentales de sumarísimos fue su identificación forzada con los expedientes que venían formando la "Sección $4^{\text {a }}$ Causas", con la intención de presentarlas como continuación natural de la jurisdicción militar tradicional: esta inserción intelectual se hizo, en primer lugar, anotando físicamente esta palabra en las cartelas de los legajos en los que fueron instalados y en los listados y cajones de los ficheros que servían para recuperarlas, de modo que la denominación de "sumarísimo", que había sido utilizada habitualmente durante su tramitación, se fue diluyendo ante otra menos comprometida.

En segundo lugar, al igual que había ocurrido con las causas militares, junto a los sumarísimos se instalaron todo tipo de procedimientos penales y no penales. Incluso pueden encontrarse entre los sumarísimos diligencias previas o expedientes informativos referidos a víctimas de las actuaciones nacionalistas o a denuncias contra agentes de la Guardia Civil por maltrato o asesinato. Esta confusión intencionada mantenida a lo largo de la dictadura contribuyó a facilitar un discurso de cuestionamiento de la naturaleza represiva de los sumarísimos como serie documental.

\section{CONCLUSIONES}

\section{Archivos mutados, enmascarados y desfigurados}

Los documentos constituyeron un elemento medular de la intensidad ideológica propia del contexto en el que se sitúa este dossier, por lo que este artículo ha intentado exponer el modo en el que estudiar la trayectoria de un fondo documental es necesario para comprender de forma completa las necesidades y aspiraciones del orden social que maniobró con cada uno de ellos. Los archivos que se han presentado como estudio de caso no son simples testimonios históricos, sino que funcionaron como un agente más en sus respectivos terrenos de revolución social, orden social republicano, conciencia de clase, victoria bélica o de imposición por la fuerza del Nuevo Estado. 
Como se ha explicado en el primer apartado, sobre algunos archivos se dieron estrategias de eliminación o de distracción al verse amenazados tras caer el orden social republicano que los generó. En primer lugar, existió por parte de los anarquistas una vinculación entre sus convicciones políticas y la destrucción de los antecedentes penales y otra documentación pública que perpetuaba, a su juicio, las relaciones injustas de poder, y a pesar de todo la huella de los archivos eliminados permanece hoy como vacío elocuente en diferentes archivos-repositorio. En segundo lugar, el archivo ideológico republicano, el Archivo de la Guerra, tuvo que desprenderse de su estructura de dispositivo de conciencia de clase para sobrevivir disgregado como patrimonio bibliográfico. En tercer lugar, como resultado de la estrategia de mutación que les permitió sobrevivir en una Europa en guerra, los archivos exiliados o bien no han sido capaces de recuperar su naturaleza pública original una vez repatriados, o ni siquiera han conseguido volver.

En el segundo apartado se ha expuesto la sofisticada estrategia documental de los Servicios de Inteligencia franquista y su desenlace en una división del archivo en tres partes siguiendo distintas necesidades funcionales de la dictadura. Lo relatado pone de relieve que incluso cuando la fracturación del archivo se produce bajo la cobertura e impulso del poder establecido, el resultado es un enmascaramiento del conjunto orgánico original con las consecuencias de la dispersión física, la descripción divergente y una visibilidad precaria: el archivo sigue estando, siendo una parte visible y debiendo adivinarse lo relativo a la oculta. Es este caso de estudio el que mejor demuestra que el archivo-repositorio impone sobre los archivos-orgánicos sus propias marcas, iluminando determinados documentos (los enmarca, los nombra, los orienta hacia sí) y negando a otros que quedan fuera de él.

El desarrollo del tercer apartado ha requerido el examen detenido de sumarísimos de un amplio ámbito territorial y cronológico, cierto distanciamiento en el estudio de la literalidad engañosa de la normativa sobre justicia de Guerra aprobada entre 1936 y 1963, y la comparación con las causas militares de otros períodos. Tras este proceso, se han extraído las diferencias sustanciales de los sumarísimos como documentación, con estrategias archivísticas que incluyeron actuaciones de diseño documental, de recuperación de la información y de organización archivística. Todo ello 
generó un macizo documental de formalidad jurídica que desfiguró la intención originaria de utilizar los sumarísimos como dispositivo de control social, por un lado, y de criminalización social de las personas condenadas, por otro.

Para reflexionar sobre el rol de los archivos en la conformación y consolidación del orden social se han analizado las estrategias archivísticas sobre cada uno de los fondos documentales seleccionados. Podría decirse que el archivo funciona como una suerte de imagen distorsionada resultado del uso de un determinado tipo de espejo o de la observación a través de lentes ensambladas. El punto de partida para la investigación de su naturaleza documental ha sido el cuestionamiento de su organización interna, de sus instrumentos de descripción e, incluso, de su identificación.

El desarrollo expuesto ha tratado de evidenciar el modo mediante el cual los archivos distraen una información al mismo tiempo que subrayan otra, deslizan en el olvido unos datos y hechos, y conmemoran con triunfalismo otros. Se trata de una investigación en los archivos-repositorio, pero, fundamentalmente, es una investigación de los archivos y de sus estrategias. De este modo, los argumentos que se han ido exponiendo no se fundamentan en las políticas generales e institucionales de patrimonio documental, ligadas a una determinada selección y construcción de la memoria oficial, sino en su contextualización y su resignificación a la luz de las circunstancias de su generación, organización y utilización a lo largo del tiempo, y, por lo tanto, establecen conclusiones generalmente divergentes de las establecidas por esta memoria oficial.

Y todas esas circunstancias, si se desconocen o se obvian, afectan a la comprensión de la información pública conservada en los archivos-repositorio. "Si no puedes convencerlos, confúndelos", decía Harry Truman inspirándose en el pasaje bíblico del Libro de Job, "Confunde a mis enemigos, y no los dejes que triunfen". La propia lucha por el acceso a los documentos, sin tener en cuenta estas estrategias archivísticas, es una lucha por acceder a una información confusa. El Archivo debe ser estudiado por sí mismo, porque sólo así sus deformaciones y sus silencios devienen elocuentes.

\section{BIBLIOGRAFÍA}


Águila Torres, Juan José del, “La represión política a través de la jurisdicción de guerra y sucesivas jurisdicciones especiales del franquismo", Hispania Nova, $\mathrm{n}^{\mathrm{o}} 1$ Extraordinario, (2015). https://erevistas.uc3m.es/index.php/HISPNOV/article/view/2873

Alonso Rodríguez, Henar, Organización de los fondos del Archivo General Militar de Ávila Henar Alonso Rodríguez. Boletín del Sistema Archivístico de Defensa, ${ }^{\circ}$ 22 (2012). https://publicaciones.defensa.gob.es/media/downloadable/files/links/b/o/boletin sad_22.pdf

Álvarez Lopera, José. La política de bienes culturales del gobierno republicano durante la Guerra Civil española, Madrid: Ministerio de Cultura, 1982.

Amorós, Miquel. José Pellicer. El anarquista integro. Vida y obra del fundador de la heroica Columna de Hierro. Barcelona: Virus Editorial, 2009.

Antebi, Andrés, González, Pablo, Ferré, Teresa y Adam, Roger Adam. Gráfica anarquista. Fotografía y revolución social 1936-1939, Barcelona: Ajuntament de Barcelona, 2020.

Barriobero y Herrán, Eduardo. El Tribunal Revolucionario de Barcelona, 1936-1937. Sevilla: Espuela de Plata, 2007.

Borges, Jorge Luis. “La Biblioteca total”, en Revista Sur, no 59 (8), agosto 1939.

Carretero Miramar, José Luis. Eduardo Barriobero. Las luchas de un jabali, Madrid: Queimada, 2017.

García-Oliver, Juan. El eco de los pasos. París: Ruedo Ibérico, 1978.

Gómez Bravo, Gutmaro, "La información retrospectiva: ocupación del territorio y clasificación de la población en el Ejército del Norte", Sancho el Sabio. Revista de cultura e investigación vasca, $\mathrm{n}^{\mathrm{o}}$ extra 1 (2018), pp. 116-118. https://revista.sanchoelsabio.eus/index.php/revista/article/view/200

González Calleja, Eduardo, "Construcción y defensa del Estado en la Segunda República Española (1931-1936)", Crónica Jurídica Hispalense: revista de la Facultad de Derecho, no 13 (2015).

González Quintana, Antonio, "Fuentes para el estudio de la represión franquista en el Archivo Histórico Nacional, sección Guerra Civil", Espacio, Tiempo y Forma, Serie V, Historia Contemporánea, t.7 (1994), pp.479-508. Recuperado el 11-062020 desde: http://revistas.uned.es/index.php/ETFV/article/view/2983

Heiber, Morten y Ros Agudo, Manuel, La trama oculta de la Guerra Civil. Los servicios secretos de Franco 1936-1939, Barcelona: Crítica, 2006.

Jiménez Villarejo, Carlos, "La destrucción del orden republicano (apuntes jurídicos)". Hispania Nova. $\mathrm{N}^{\mathrm{o}}$ 7, (2007). http://hispanianova.rediris.es/7/dossier/07d006.pdf.

Melgar Camarzana, Manuel y López Wehrly, Silvia Alicia, Los archivos militares: qué son y cómo se tratan (Gijón: Trea, 2010), pág. 114.

Ministerio De Justicia, 1943, Causa General. La dominación roja en España. Astorga: Akrón, 2008. 
Pastor Núñez, Guillermo. "Un archivo vivo de la Guerra Civil española. El auténtico archivo de la guerra" en Kamchatka. Revista de análisis cultural, n 14 (2019), 93-110, https://ojs.uv.es/index.php/kamchatka/article/view/14154

Pedraz Penalva, Ernesto, "La Administración de Justicia durante la Guerra Civil en la España Nacional", Justicia en guerra: Jornadas sobre la administración de justicia durante la Guerra Civil Española, Madrid, Ministerio de Cultura, 1990.

Peirats, Josep. La CNT en la Revolución Española. Tomo I. Madrid: CNT-AIT, 1978.

Pérez-Olivares García, Alejandro "La victoria bajo control: ocupación, orden público y orden social del Madrid franquista (1936-1948)". Tesis doctoral, Universidad Complutense de Madrid, 2017. https://eprints.ucm.es/45481/1/T39392.pdf

Rial Quintela, María del Carmen, Los fondos documentales del franquismo en los archivos militares, La alargada sombra del franquismo (Granada: Comares, 2019), pp. 397-418.

Tello, Andrés Maximiliano. Anarchivismo. Tecnologías politicas del archivo. Madrid: La Cebra, 2018.

Villar Ferrero, José Luis, "Justicia y Revolución en 1936. Las Oficinas Jurídicas de Cataluña". Tesis doctoral, Universitat de Barcelona, 2012. https://www.tdx.cat/handle/10803/284477

Yusta Rodrigo, Mercedes, "Una guerra que no dice su nombre. Los usos de la violencia en el contexto de la guerrilla antifranquista (1939-1953)", Historia Social, n 61 (2008). http://www.jstor.org/stable/40658119 